\title{
The extent of mycorrhizal colonization of roots and its influence on plant growth and phosphorus content
}

\author{
Kathleen K. Treseder
}

Received: 28 September 2012 / Accepted: 6 March 2013 /Published online: 20 March 2013

(C) Springer Science+Business Media Dordrecht 2013

\begin{abstract}
Aims The most common metric of arbuscular mycorrhizal fungal (AMF) abundance is percent root length colonized (PRLC) by mycorrhizal structures. Frequently, plants with greater PRLC are assumed to receive more nutrients (such as phosphorus, $\mathrm{P}$ ) from their mycorrhizal symbionts, leading to greater plant growth. Nevertheless, the functional significance of this metric remains controversial. In this review, I discuss whether manipulations of PRLC generally led to changes in plant biomass and $\mathrm{P}$ content, and whether AMF taxa and plant functional groups influence these relationships.

Methods I conducted a meta-analysis of laboratoryand field-based trials in which mycorrhizal colonization was directly altered compared to unmanipulated controls. For each trial, I calculated (1) the difference in PRLC ( $\triangle$ PRLC) between the treatments, and (2) the response ratio of plant biomass. In a subset of these studies, the response ratio of $\mathrm{P}$ content of host plants could also be calculated.
\end{abstract}

Responsible Editor: Philippe Hinsinger.

Electronic supplementary material The online version of this article (doi:10.1007/s11104-013-1681-5) contains supplementary material, which is available to authorized users.

K. K. Treseder $(\bowtie)$

Department of Ecology and Evolutionary Biology,

University of California Irvine,

Irvine, CA 92697, USA

e-mail: Treseder@uci.edu
Results The response ratio of plant biomass and $\mathrm{P}$ content rose significantly and exponentially as $\triangle \mathrm{PRLC}$ increased. Nevertheless, $\triangle$ PRLC explained only a fraction of the variation in response ratios in each case. Moreover, AMF taxa varied in their effects on biomass per unit $\triangle$ PRLC. In addition, plant functional groups differed in effects on plant $\mathrm{P}$ content per unit $\triangle \mathrm{PRLC}$, with $\mathrm{C} 4$ grasses responding most strongly.

Conclusions It appears that as the extent to which plant roots are colonized by AMF increases, plant growth and $\mathrm{P}$ content often increase, although substantial variability exists among trials. As others have found, a likely mechanism for this relationship is increased transfer of P (and perhaps other nutrients) through the more-prevalent mycorrhizal structures.

Keywords Arbuscular mycorrhizal fungi . Meta-analysis · Percent root length colonized . Phosphorus · Plant biomass · Taxonomy

\section{Introduction}

Arbuscular mycorrhizal fungi facilitate the growth of many plants by improving nutrient acquisition from soil (Smith and Read 2008; Smith and Smith 2011b). This generally mutualistic relationship has been wellestablished via hundreds of studies for more than 50 years (Mosse 1957; Hoeksema et al. 2010 and references therein). Essentially, these studies have compared plant growth or nutrient status between plants growing 
with and without AMF inocula. On average, plants that are colonized by AMF grow 3.1 times larger than do uncolonized control plants (Hoeksema et al. 2010). Arbuscular mycorrhizal fungi are thought to be more efficient at scavenging for soil nutrients, owing to their larger surface-to-volume ratios (Sanders and Tinker 1973). This ability is particularly important for acquisition of $\mathrm{P}$, which is relatively immobile in soil (Nye and Tinker 1977). In this review, I will first describe how researchers apply and interpret one metric of AMF dynamics: percent root length colonized (PRLC) by AMF. Although PRLC is often used to infer benefits of AMF on plant growth and $\mathrm{P}$ content, a number of factors could modify these relationships. These include AMF taxa, plant functional groups, and environmental conditions. Therefore, I next discuss the state of knowledge regarding relationships between PRLC and benefits to host plants, which factors directly influence PRLC, and how AMF characteristics and plant functional groups can modify the effect of PRLC on plants. Finally, I conduct a meta-analysis of studies that have directly manipulated PRLC and measured effects on plant biomass and plant $\mathrm{P}$ content.

How are arbuscular mycorrhizal fungi assessed?

One common interpretation is that greater density of AMF in plant roots leads to greater benefits for the host plant. The standard metric for AMF abundance is PRLC (reviewed in Vierheilig et al. 2005). This technique involves clearing and staining fine roots for AMF hyphae, vesicles, and arbuscules, and using a line intercept method to determine the proportion of root length colonized by these structures (Koske and Gemma 1989; McGonigle et al. 1990). The measurement of PRLC is relatively inexpensive and technically undemanding (albeit time-intensive). For these reasons, this technique is attractive and accessible to a wide variety of researchers.

Consequently, the measurement of PRLC by AMF is frequently reported in the literature, and is often placed in the context of benefits to plants by the AMF fungus. In this case, "benefit" refers to improved growth or $\mathrm{P}$ content of AMF-colonized plants compared to uncolonized plants. For instance, 60 original research articles were published by Mycorrhiza in 2010 and 2011 that examined AMF. Of these, 40 reported PRLC by AMF. The authors of 23 of the 40 studies interpreted PRLC in relation to some aspect of plant benefit, most commonly plant growth or biomass (12 studies), plant $\mathrm{P}$ uptake (10 studies), and/or other nutrients (2 studies). Often, the authors used patterns of PRLC to interpret those of plant growth or P uptake, by suggesting that higher values of PRLC led to greater plant benefits.

Percent root length colonized by AMF structures is not the only measure of AMF abundance (Vierheilig et al. 2005). Some investigators report percent root length colonized by arbuscules, specifically, since arbuscules are often the primary site of nutrient and $\mathrm{C}$ exchange between the fungus and plant (Smith and GianinazziPearson 1990; Ezawa et al. 2002; Smith and Read 2008). Nevertheless, arbuscules are more ephemeral than other intraradical AMF structures, and they can be difficult to observe, so this metric is rarely reported (Allen 1983; Brundrett 2009). In addition, the role of arbuscules have not been fully confirmed, and other exchange sites - including coiling AMF - are possible (Brundrett 2004; Brundrett 2009). Total root length colonized by AMF, either on a per-plant or per-ground area basis, has also been used (e.g., Nadian et al. 1997; Allen 2001). This index may be a closer estimate of AMF abundance within a plant or ecosystem, respectively. Nevertheless, investigators must measure root length to calculate this variable, so it is more timedemanding - and sometimes less feasible - than measuring PRLC alone. Arbuscular mycorrhizal fungi also produce extraradical hyphae that extend into the surrounding soil much further than do root hairs (Rhodes and Gerdemann 1975; Read 1984; Friese and Allen 1991). These hyphae are responsible for nutrient uptake by AMF from soil, so standing hyphal length in soils is another frequently-used index of AMF biomass (e.g., Bardgett 1991; Sylvia 1992; Schweiger and Jakobsen 2000; Hart and Reader 2002a). Quantitative PCR of AMF-specific DNA from roots or soil is another option (Filion et al. 2003; Alkan et al. 2004; Isayenkov et al. 2004; Alkan et al. 2006; Gamper et al. 2008), although this technique is relatively technically demanding and expensive. Finally, phospholipid or neutral lipid fatty acids can indicate biomass of AMF (Olsson et al. 1995; Allison and Miller 2005), although this technique is used less frequently than is PRLC. Each of these assays provides an index of the standing biomass (or gene copy number) of AMF. Thus, they are not necessarily a measure of the activity or function of the symbiosis, especially since nutrient uptake and $\mathrm{C}$ use can vary among and within AMF tissues (reviewed in Smith and Read 2008). 
Does higher PRLC yield greater plant benefits?

To date, few syntheses have directly tested the robustness of PRLC of AMF as an indicator of plant benefits. In a recent meta-analysis of agricultural systems, Lekberg and Koide (2005) observed that increases in PRLC were associated with stronger effects on biomass of crop plants. Feldmann et al. (2009) examined effects of corn-derived AMF inocula on growth of seven host plants. They concluded that PRLC influenced plant growth in a non-linear fashion, with a threshold at 20 $30 \%$ PRLC. Below this threshold, plant benefits of AMF colonization were not evident; above this threshold, plant benefits existed but did not co-vary with PRLC. Sanders et al. (1977) reported that in three of four isolates of AMF, the flux of $\mathrm{P}$ into onion roots increased linearly with PRLC. Fitter and Merryweather (1992) did not find striking evidence for relationships between PRLC and plant P uptake in observational studies in which PRLC was not directly manipulated. In a meta-analysis focusing on ectomycorrhizal fungi, Karst et al. (2008) found no significant relationship between plant biomass response and PRLC or percentage root tips colonized by ectomycorrhizal fungi. Altogether, the suitability of PRLC as an index of AMF effectiveness is a matter of debate (Smith and Read 2008), and it has not yet been quantitatively tested across a broad range of studies that include natural as well as agricultural systems.

What influences PRLC?

Percent root length colonized is essentially the product of two variables: standing root length and AMF abundance. Thus, changes in PRLC could result from changes in standing root length, and may not necessarily be related to AMF abundance. Since standing root length (as $\mathrm{m}$ root plant ${ }^{-1}$ or $\mathrm{m}$ root $\mathrm{m}^{-2}$ ground area) varies among plant species (Einsmann et al. 1999; Kembel and Cahill 2005) and developmental stages (Troughton 1956; Bartelink 1998), as well as environmental characteristics such as ecosystem type (Schenk and Jackson 2002a), season (Hendrick and Pregitzer 1996), soil moisture (Schenk and Jackson 2002b), nutrient availability (Chapin 1980; Reynolds and Dantonio 1996; Ostertag 2001), and atmospheric $\mathrm{CO}_{2}$ (Stulen and Denhertog 1993; Pritchard et al. 2008), any shifts in PRLC may occur due to changes in colonized root length, standing root length, or both.
What might influence the effect of PRLC on plants?

Arbuscular mycorrhizal fungal taxa, morphology, and activity

Arbuscular mycorrhizal fungal taxa vary in their contribution to nutrient uptake by plants (Munkvold et al. 2004; Smith and Smith 2011b). Some genera, such as Scutellospora and Gigaspora, construct more extensive extraradical hyphae per unit PRLC, which could result in better nutrient acquisition (Hart and Reader 2002a, b; Treseder 2005; Maherali and Klironomos 2007; Powell et al. 2009). Other genera such as Acaulospora, Glomus, Funneliformis (i.e., the Glomus mosseae clade), and Rhizophagus produce less extraradical hyphal biomass, and may serve as poorer mutualists (Hart and Reader 2002b; Maherali and Klironomos 2007; Powell et al. 2009). Nevertheless, greater production of extraradical hyphae does not always lead to stronger plant benefits (Graham and Abbott 2000; Klironomos 2003). Since ratios between PRLC and extraradical hyphal biomass vary among AMF taxa, it is not clear how well PRLC predicts host plant benefit across diverse AMF taxa (Abbott and Robson 1985; Hart and Reader 2002a). In addition, AMF can in some cases negatively affect plant growth (Smith and Smith 2011a; Smith and Smith 2011b, 2012). High PRLC could cause decreased benefits or negative effects on plants in this instance.

The presence of AMF structures in a root does not necessarily indicate that those structures are translocating C and P (Fitter 1991). Indeed, AMF structures appear to grow most rapidly, and transfer $\mathrm{C}$ and $\mathrm{P}$ most actively, when they are located near a growing root tip (Buwalda et al. 1982; Walker and Smith 1984). As the AMF structures age and become more distant from the root tip, activities decline (Tisserant et al. 1993; Tisserant et al. 1996). Thus, some fraction of intraradical AMF structures may not be actively contributing to plant $\mathrm{P}$ uptake, especially where older roots are present (Allen 2001).

\section{Plant functional groups}

Plant functional groups can influence relationships between PRLC and benefits to host plants through a number of mechanisms. Plant functional groups are groups of species that are similar in their role in community or ecosystem dynamics, and classifications include $\mathrm{C} 3$ and 
C4 grasses, woody plants, forbs, and N-fixers (e.g., Kattge et al. 2011). These functional groups vary in standing root length (Jackson et al. 1997; Einsmann et al. 1999; Kembel and Cahill 2005), which partly determines PRLC (see "What influences PRLC?", above). A number of investigators have suggested that fastversus slow-growing plants (or roots) should differ in their responses to AMF colonization, with arguments for and against fast-growers being more dependent on AMF (Brundrett 1991; Koide 1991; Allsopp and Stock 1993; Smith and Smith 1996). In addition, plant functional groups may select for AMF taxa that elicit particular $\mathrm{C}$ costs or $\mathrm{P}$ benefits. As a result, effect sizes for plant biomass or $\mathrm{P}$ content could differ per unit PRLC. Indeed, plant and AMF taxa appear to interact in terms of their effects on plant biomass and P content (e.g., McGee 1990; Siqueira et al. 1998; van der Heijden et al. 1998; Helgason et al. 2002; Smith et al. 2004; Bunn et al. 2009; Lendenmann et al. 2011). Hoeksema et al. (2010) performed a meta-analysis of plant responses to the presence versus absence of AMF, and they found that plant functional group explained the greatest amount of variation among studies. Specifically, they reported that $\mathrm{C} 4$ grasses and non-N-fixing plants tended to be more responsive to AMF colonization than were $\mathrm{C} 3$ grasses and $\mathrm{N}$-fixing plants (Hoeksema et al. 2010). Since these functional groups are relatively sensitive to the presence versus absence of AMF, then they may likewise be more responsive to changes in PRLC.

\section{Meta-analysis}

I examined these issues by conducting a meta-analysis of published trials in which PRLC by AMF was directly manipulated, and then responses in plant biomass or plant $\mathrm{P}$ content were assessed. In many cases, the taxonomic identity of AMF was provided, so I could also test for phylogenetic effects on relationships between PRLC and host plant benefit. I tested three hypotheses: (1) overall, more extensive colonization of plant roots by AMF leads to greater plant benefits, in terms of increases in biomass and $\mathrm{P}$ content; (2) AMF taxa vary in their degree of host plant benefit per unit PRLC; and (3) plant functional groups differ in the benefit they receive from AMF per unit PRLC. In examining the second hypothesis, I capitalized on recent advances in the taxonomy of AMF (Redecker 2002; Da Silva et al. 2006; Redecker and
Raab 2006; Krüger et al. 2012; Stuermer 2012; Young 2012). Most of the genera used here as AMF inocula have been sequenced in the $28 \mathrm{~S}$ rDNA region (Da Silva et al. 2006; Redecker and Raab 2006), which allowed me to estimate phylogenetic relationships. In addition, many taxa previously identified as Glomus species have been reassigned to new genera, which allowed higher-resolution assessments of taxon effects.

Methods

\section{Sources of data}

Meta-analyses were performed on previously-published data that met specific criteria (Online Resource 1). I selected laboratory and field trials in which AMF colonization was directly manipulated, usually via a combination of soil sterilization, addition of AMF inocula, serial dilution of soils or inocula, or fungicide applications. Most laboratory trials used sterilized soils; control treatments harbored low or no PRLC, while enriched treatments received AMF inocula. Other laboratory trials used whole soil to represent a baseline PRLC level, in comparison with a reduced-PRLC treatment obtained via dilution with sterile soil, fumigation, or treatment with fungicides. Field trials included those with transplanted, AMF-colonized versus uncolonized seedlings; plots augmented with AMF inocula; and plots treated with fumigants or fungicide. Because the baseline nutrient status of host plants can strongly influence responses to AMF (Hoeksema et al. 2010), I included only trials in which no type of fertilizer was applied. This constraint eliminated many trials of AMF benefits on host plants. I also did not include trials that used nonsoil based growth media; or soils contaminated with heavy metals, augmented with organic contaminants or additives, or artificially acidified. If a particular publication reported results from more than one study system that could reasonably be considered independent (e.g. geographical location, ecosystem, dominant vegetation type, or AMF inoculum), each system was designated as a different trial.

Of all trials that met these criteria, 195 reported plant biomass for each treatment; 118 reported plant $\mathrm{P}$ content (i.e., total $\mathrm{P}$ contained within the whole plant or the shoot). Many of the trials with inocula from the order Glomerales or inocula with multiple species were also included in the meta-analysis by Hoeksema et al. (2010). 


\section{Data assimilation}

For each trial, I recorded the mean PRLC of the "lower PRLC" and "higher PRLC" treatments, and calculated the difference between the two as $\triangle \mathrm{PRLC}$. The unit is percentage point, which is the arithmetic difference between two percentages. In addition, I recorded the corresponding plant biomass or plant $\mathrm{P}$ content for each treatment. Effect sizes were calculated as response ratios (unitless):

$$
\begin{aligned}
& \text { Biomass Effect Size }=\left(\frac{\text { Biomass }_{\text {higher } P R L C}}{\text { Biomass }_{\text {lower } P R L C}}\right) \\
& \text { Phosphorus Effect Size }=\left(\frac{P_{\text {higher } P R L C}}{P_{\text {lower PRLC }}}\right)
\end{aligned}
$$

where "Biomass" was the total plant biomass (if available). If total plant biomass was not provided, then I recorded aboveground plant biomass instead. In the majority of trials, investigators measured biomass by harvesting standing plant tissue and then determining dry mass, although a few assessed plant height (Online Resource 1). Likewise, "P" was recorded for the whole plant (where available), and for shoots (i.e., all aboveground biomass) otherwise. Phosphorus was provided as units total P per plant (or shoot), and it was primarily determined via colorimetry/spectrophotometry (Online Resource 1).

\section{Estimate of AMF phylogeny}

I searched GenBank for representative, high-quality $28 \mathrm{~S}$ sequences of each AMF genus represented in the selected studies (www.ncbi.nlm.nih.gov/genbank/, accessed May 20, 2012). The taxonomy of Schüßler and Walker (2010) was used to define AMF genera. High-quality $28 \mathrm{~S}$ sequences were available for each genus except Sclerocystis. I downloaded representative sequences for all available genera (Online Resource 2), and trimmed them where necessary to remove extraneous regions. I then constructed an alignment and estimated a phylogeny using SATé under the default Saté-II-fast setting (Liu et al. 2009; Liu et al. 2012). MAFFT 6.717 was used as the aligner (Katoh et al. 2009), and a maximum likelihood tree was created with FastTree 2.1.4 under the GTR CAT model (Price et al. 2010).

\section{Statistics}

In every case, tests were performed on ranked data owing to non-normal distributions. Except where noted, Systat version 10.2 software was used. To test Hypothesis 1, general linear models were applied with $\triangle \mathrm{PRLC}$ as the independent variable and biomass effect size or P effect size as the dependent variable in each case. In addition, I checked for potential influences of inoculum complexity (single taxa versus multiple taxa), study setting (laboratory versus field), and lower PRLC value by conducting sequential general linear models with $\triangle \mathrm{PRLC}$ as one independent variable plus either inoculum complexity, study setting, or lower PRLC as an additional independent variable. I included lower PRLC value in the analysis to test whether the absolute value of PRLC - in addition to the change in PRLC - influenced plant responses.

To test Hypothesis 2, I focused on trials with singletaxa inocula only. In addition, some Glomus species had not received a formal taxonomic designation (i.e., Glomus sensu lato), so they were omitted from tests of Hypothesis 2. First, I applied general linear models with $\triangle$ PRLC and genus of AMF inoculum as independent variables, and biomass effect size or $\mathrm{P}$ effect size as the dependent variables. A significant genus effect would support the hypothesis that AMF taxa vary in their effect on plant biomass or P concentration. Second, I calculated the effect size per unit $\triangle$ PRLC for each study. Where indicated, Tukey post hoc tests were used to check for pairwise comparisons among AMF genera. Third, a Mantel test with 1000 random iterations was used to check for phylogenetic signals in biomass effect size per unit $\triangle$ PRLC (Liedoff 1999). Specifically, sequence identity and the absolute difference between effect size per unit $\triangle$ PRLC were calculated for each pairwise comparison among genera. A significant phylogenetic signal (i.e., negative correlation between variables) would indicate that more closely-related taxa elicit similar plant benefits. (Trials with Sclerocystis species were not included in tests for phylogenetic signal, since this genus was not represented in the maximum likelihood tree).

For Hypothesis 3, general linear models were applied with $\triangle P R L C$ and plant functional group as independent variables, and biomass effect size or P effect size as the dependent variable. Tukey pairwise tests among plant functional groups were conducted where indicated.

\section{Results}

\section{Plant biomass}

The response ratio of plant biomass increased significantly with $\triangle \mathrm{PRLC}$ across all trials, within trials with 
multiple taxa, and within trials with Funneliformis species as single inoculants (Fig. 1, Online Resource 3, $P<0.001$ in each case). However, $\triangle \mathrm{PRLC}$ explained only a fraction of the variation in the response ratio $\left(r^{2}=0.118-0.363\right)$. For trials with single inocula, the genus of the AMF fungus significantly influenced the degree to which plant biomass responded to $\triangle$ PRLC (Fig. 2, Online Resource 3). Specifically, Funneliformis (i.e., the Glomus mosseae clade) had a significantly larger effect on plant biomass per unit $\triangle$ PRLC than did Racocetra. Nevertheless, there was no significant phylogenetic conservation of plant benefit when all phylogenetic scales were considered ( $g=0.132, P=0.483$ ). In other words, more closelyrelated taxa did not generally produce similar effects on plant biomass per unit $\triangle$ PRLC. Inocula with multiple AMF taxa did not significantly differ from inocula with single taxa in terms of their effects on plant biomass (Online Resource 3, $P=0.514$ ), and neither did laboratory- versus field-based trials (Online Resource 3, $P=0.360$ ). The lower value of PRLC within each trial was not significantly related to plant biomass effects $(P=0.654)$. Plant functional groups differed from one another in biomass effect, but only marginally significantly (Fig. 3, Online Resource 3, $P=0.068)$.

\section{Plant P content}

Increases in plant $\mathrm{P}$ contents were greater when $\triangle \mathrm{PRLC}$ was more pronounced, and this relationship was significant across all trials (Fig. 4, Online Resource 3, $P<0.001$ ), in trials with multiple AMF taxa $(P=0.009)$, and in trials with single AMF taxa as inocula $(P<0.001)$, albeit with high variability in each case $\left(r^{2}=0.223-0.274\right)$. Plant $P$ effects did not differ significantly among AMF genera (Online Resource 3). In addition, the lower PRLC value in each trial did not significantly influence $\mathrm{P}$ effects $(P=0.468)$. Moreover, single-taxa inocula did not differ significantly from multiple-taxa inocula in their effects on plant $\mathrm{P}$ concentration (Online Resource 3, $P=0.191$ ), and neither did laboratory- versus field-based trials (Online Resource 3, $P=0.213)$. Plant functional groups were associated with significantly different plant $\mathrm{P}$ effects $(P<0.001)$; $\mathrm{C} 4$ grasses displayed the highest plant $\mathrm{P}$ effect per unit $\triangle$ PRLC, and N-fixing woody plants the lowest (Fig. 3, Online Resource 3).
Fig. 1 Relationships between changes in percent root length colonized (higher PRLC - lower PRLC) and effect size of plant biomass (biomass higher $_{\text {/ }}$ biomass lower $_{\text {low }}$. Relationships are presented for all studies combined, for studies with multiple AMF taxa in the inoculum, and for studies with single AMF taxa. Each symbol represents one study. Lines are best fit regressions for significant relationships only. Statistics were conducted on ranked data. Dashed black line $=$ Funneliformis . Note $\log$ scale of vertical axis. Effect size is unitless

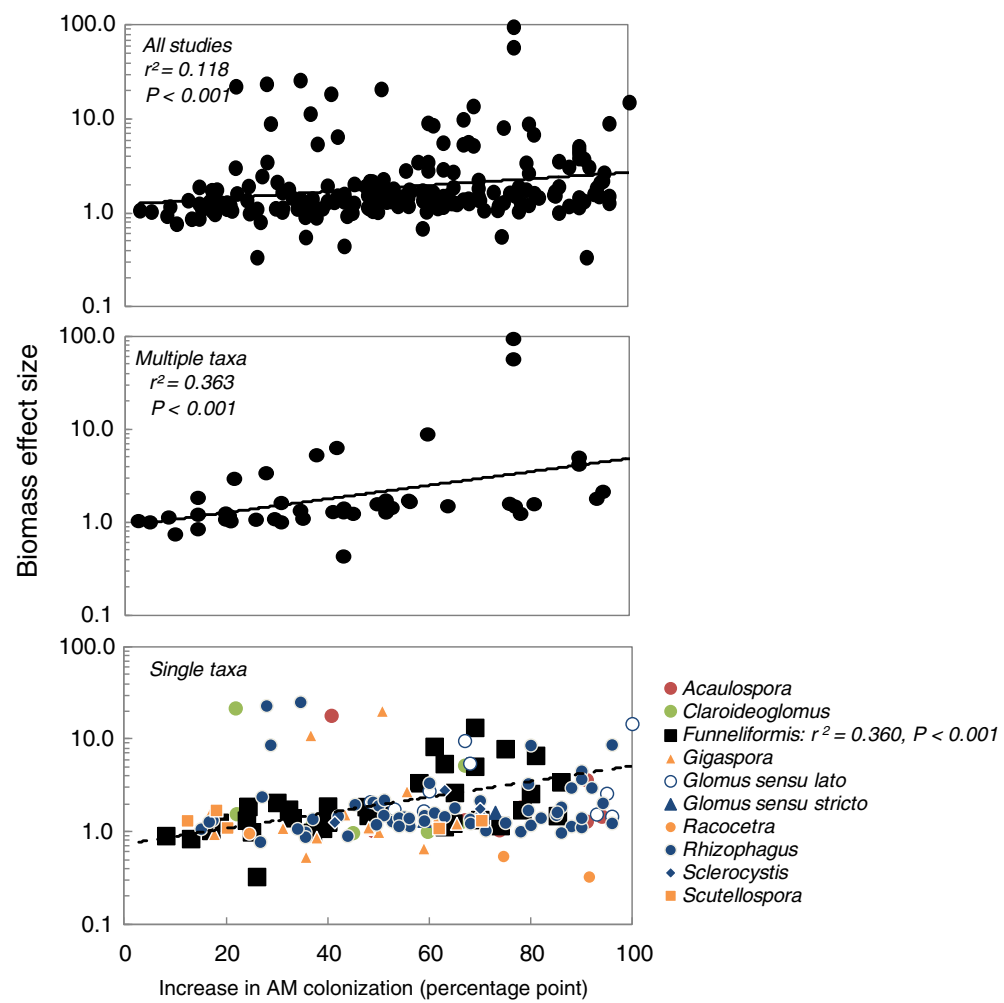




\section{Discussion}

Generally, greater PRLC by AMF was associated with better plant growth (Fig. 1). This relationship was significant when all trials that met the selection criteria were included in the analyses, although PRLC explained only $11.8 \%$ of the variability in biomass effect size. In addition, effects on plant $\mathrm{P}$ content were positively related to $\triangle \mathrm{PRLC}$ (Fig. 4). This potential mechanism is consistent with the characterization of the generally mutualistic relationship between plants and AMF (Mosse 1957, 1973; Smith and Read 2008; Smith and Smith 2011b, 2012). Indeed, a fair amount of evidence has accumulated indicating that AMF are balanced mutualisms that function by a form of regulated exchange, so that plants should support high levels of PRLC only if the AMF provide benefits (reviewed in Brundrett 2004). Nevertheless, Smith and Smith (2012) reported physiological evidence for large differences in $\mathrm{P}$ transfer by different AM fungi that would be expected to influence the size (and possible direction) of AM-mediated growth responses and total $\mathrm{P}$ uptake. This area requires more research, given that AM roots contain multiple AM fungal taxa. On average, natural ecosystems harbor 15 to $30 \mathrm{AMF}$ species (Kivlin et al. 2011). Thus, trials with multiple AMF taxa in their inocula may be particularly relevant for natural settings. In these studies, PRLC explained

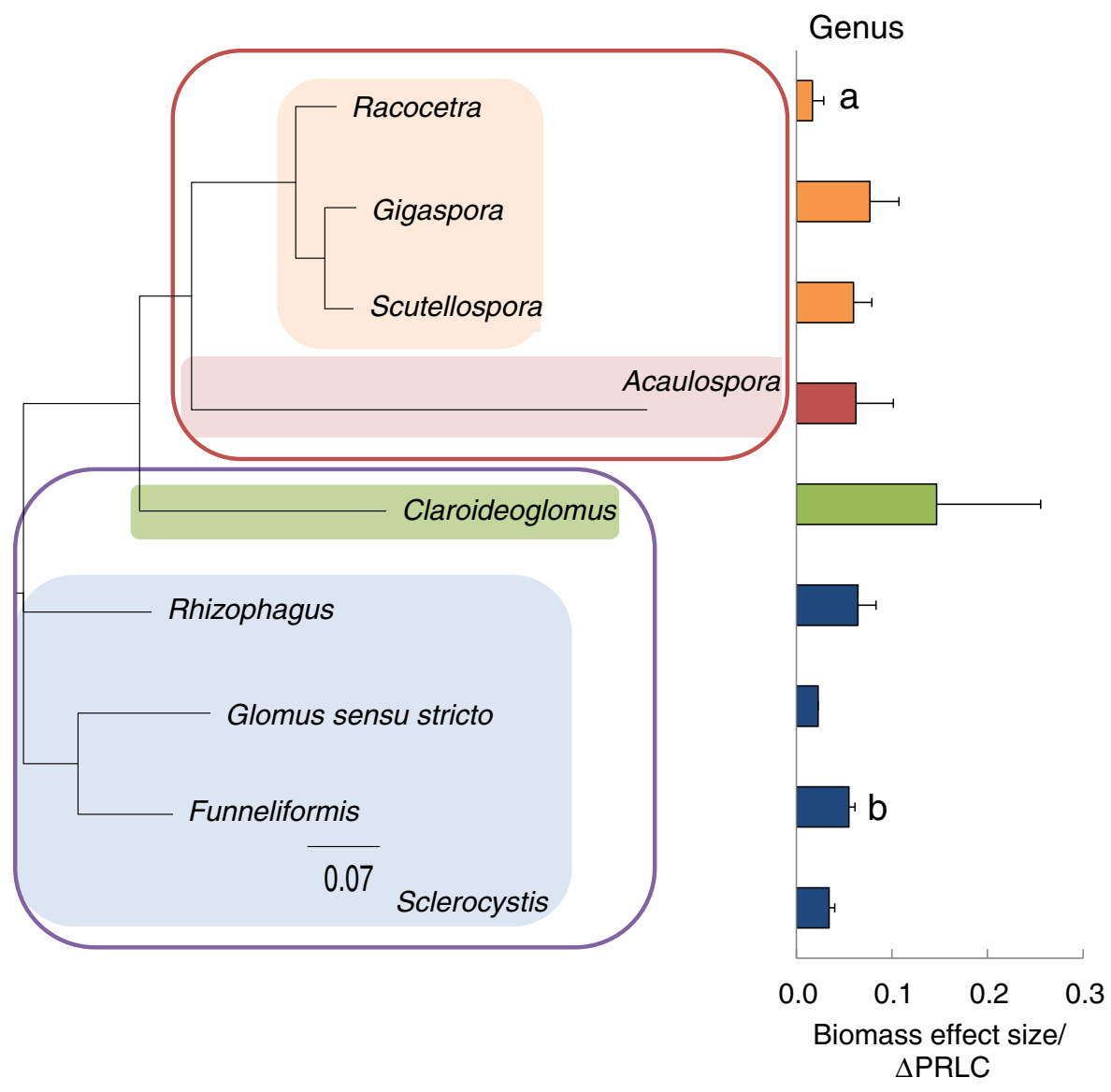

Fig. 2 Maximum likelihood tree of AMF taxa included in metaanalysis, coupled with the relative influence of AMF taxa on effect size of plant biomass per unit $\triangle \mathrm{PRLC}$ (percentage point ${ }^{-1}$ ). Tree was estimated for representative 28S rDNA sequences (Online Resource 2). Sclerocystis is a member of the Glomeraceae, but it was not included in the tree owing to lack of a high-quality sequence in this region. Colors of shaded boxes represent family (orange $=$ Gigasporaceae, red $=$ Acaulosporaceae, green $=$ Claroideoglomeraceae, blue $=$ Glomeraceae $)$. Colors of open boxes represent order (red $=$ Diversisporales, purple $=$ Glomerales). Bars are means $+\mathrm{SE}$ for each genus. Genera with different letters were significantly different from one another. Claroideoglomus, Funneliformis, and Rhizophagus species were formerly classified as Glomus. Racocetra species were formerly classified as Scutellospora or Gigaspora 
$36 \%$ of the variation in plant biomass effect and $27 \%$ in plant $\mathrm{P}$ content. Altogether, the results of this study support Hypothesis 1, and suggest that PRLC indicates (albeit very imprecisely) AMF benefits to host plants.

The relationships between $\triangle \mathrm{PRLC}$ and plant biomass and $\mathrm{P}$ effects were significant despite potential complicating factors that have been previously raised by researchers. First, PRLC is influenced by standing fine root length as well as AMF abundance. If so, variation in standing fine root length could alter PRLC even if AMF abundance (and, presumably, benefits to host plants) remains constant. Instead, it is possible that standing root length increased concurrently with AMF abundance, which could occur if plants grew more fine roots upon colonization by AMF. Second, although AMF can negatively affect the growth of host plants under certain conditions (Bever 1994; Bever et al. 1997; Johnson et al. 1997; Klironomos 2002; Castelli and Casper 2003; Hart et al. 2003; Klironomos 2003; Jones and Smith 2004; Smith and Smith 2011b, 2012), these situations were rare within this meta-analysis. In fact, a reduction in plant growth in response to increases in PRLC (i.e., a response ratio $<1.0$ ) was recorded in only 18 of the 195 trials surveyed here (Online Resource 1). Third, even though PRLC does not quantify extraradical biomass of AMF, as cited by Hart and Reader (2002a), there appears to be no substantial trade-off between construction of intraradical and extraradical structures by AMF (Powell et al. 2009). Indeed, Powell et al. (2009) reported that after accounting for shared evolutionary histories, PRLC and extraradical biomass are positively correlated among AMF taxa. Although each of these potentially confounding mechanisms could have obscurred relationships between PRLC and plant biomass and $\mathrm{P}$ effects, they do not appear strong enough to negate it.

In support of Hypothesis 2, AMF taxa varied in their influence on plant biomass (Fig. 2). Differences among AMF taxa in effects on plant biomass have been documented in numerous studies (e.g., Abbott and Robson 1985; Guissou et al. 1998; Vosátka and Dodd 1998; Clark et al. 1999; Ozgonen and Erkilic 2007; Sensoy et al. 2007; Powell et al. 2009; Watanarojanaporn et al. 2011). The results of the
Fig. 3 Effect size of plant biomass and $\mathrm{P}$ content per unit $\triangle$ PRLC (percentage point ${ }^{-1}$ ) for each plant functional group. Plant functional groups differed marginally significantly for biomass $(P=0.068)$, and significantly for $\mathrm{P}$ content $(P<0.001)$. Bars are means + SE for each plant functional group. Standard error is not presented for the "multiple functional groups" category, as it contained only one study. Plant functional groups with different letters were significantly different from one another

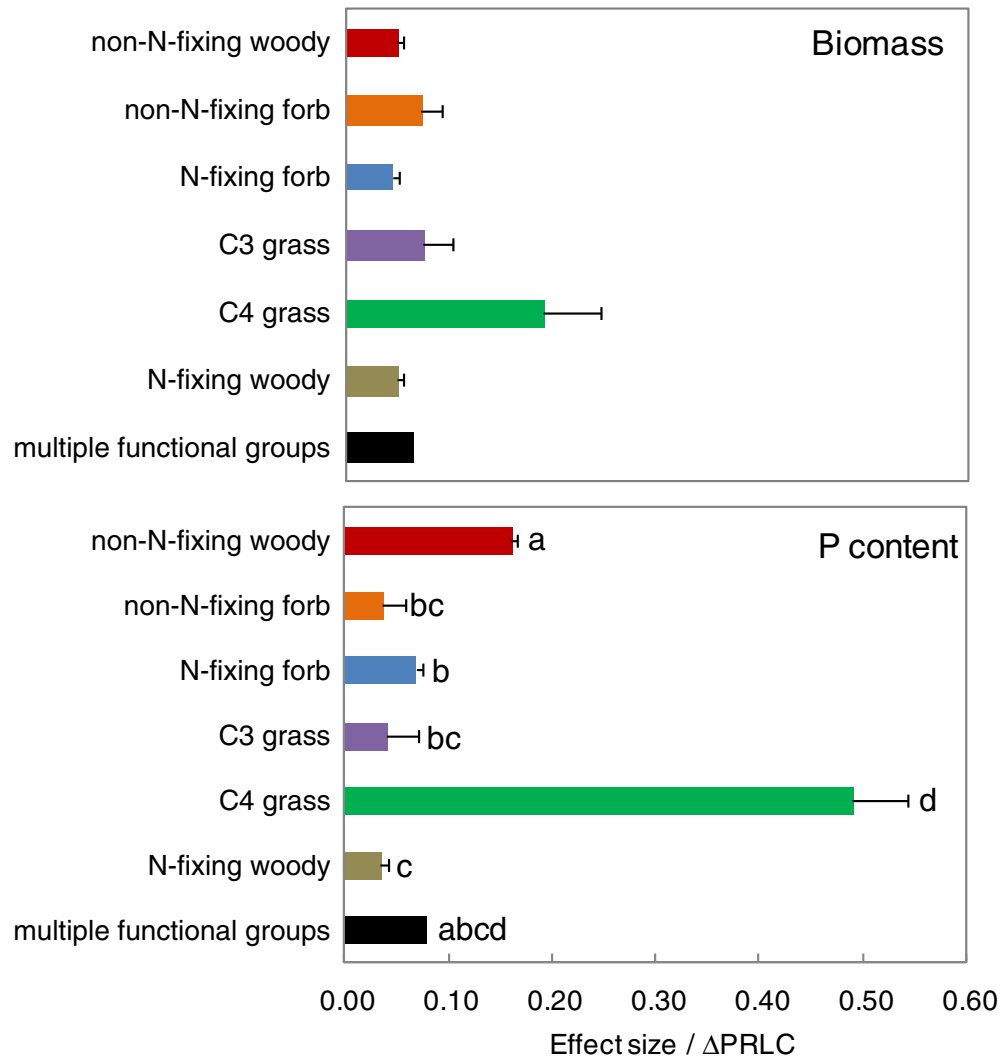


current study are not generally consistent with expectations based on investment in extraradical hyphae, arbuscules, or vesicles by AMF genera (e.g., Hart and Reader 2002a, b; Treseder 2005). Funneliformis produced the greatest effect on host plant growth, even though it does not develop extensive extraradical hyphal networks that would facilitate nutrient uptake. It is possible that shorter hyphae require less $\mathrm{C}$ to construct, and thus represent a smaller cost to the host plant. Alternately, the differences among AMF taxa could be influenced by variation in propagation biology (e.g., Abbott and Robson 1991; Friese and Allen 1991). Taxa of AMF can also vary in their ability to grow in pot cultures in general, or in specific conditions imposed by greenhouse trials, such as soil $\mathrm{pH}$ or $\mathrm{P}$ availability (Brundett et al. 1996).

The current study is broadly consistent with the meta-analysis of Hoeksema et al. (2010), who synthesized responses in plant biomass to the presence versus absence (but not PRLC) of mycorrhizal fungi. For instance, they found that plants colonized by AMF grew much larger, on average, and that P-limitation of plant growth influenced the degree of response. Nevertheless, they found that differences in effects among mycorrhizal genera were relatively unimportant, even when ectomycorrhizal and AMF genera were compared. The two studies may be inconsistent in this regard for two reasons. First, different sets of trials were used (albeit with some overlap). In the current study, certain species of Glomerales and Diversisporales differed from one another in their effects on plant biomass per unit $\triangle$ PRLC (Fig. 2). On the other hand, Hoeksema et al. (2010) focused on AMF taxa belonging to the Glomerales, so differences between AMF taxa may have been less evident. Second, I essentially tested taxa for differences in the efficiency with which they benefitted host plants, on a per-unit basis (i.e., effect size per unit $\triangle$ PRLC). This value need not necessarily coincide with total effects on plant growth by the sum of AMF structures colonizing the root system, which is
Fig. 4 Relationships between changes in percent root length colonized (higher PRLC - lower PRLC) and effect size of plant $\mathrm{P}$ content $\left(\mathrm{P}_{\text {higher }} / \mathrm{P}_{\text {lower }}\right)$. a Relationships for all studies combined $\left(\mathrm{r}^{2}=0.235, P<0.001\right.$, red solid line), across all studies with single AMF taxa (dashed line), and for studies with multiple AMF taxa in the inoculum (dotted line). b Relationships for each plant functional group (red solid line $=$ non-N-fixing woody, orange dashed line $=$ non-Nfixing forb, blue dotted line $=$ $\mathrm{N}$-fixing forb). Each symbol represents one study. Lines are best fit regressions for significant relationships only. Statistics were conducted on ranked data. Note log scale of vertical axis. Effect size is unitless

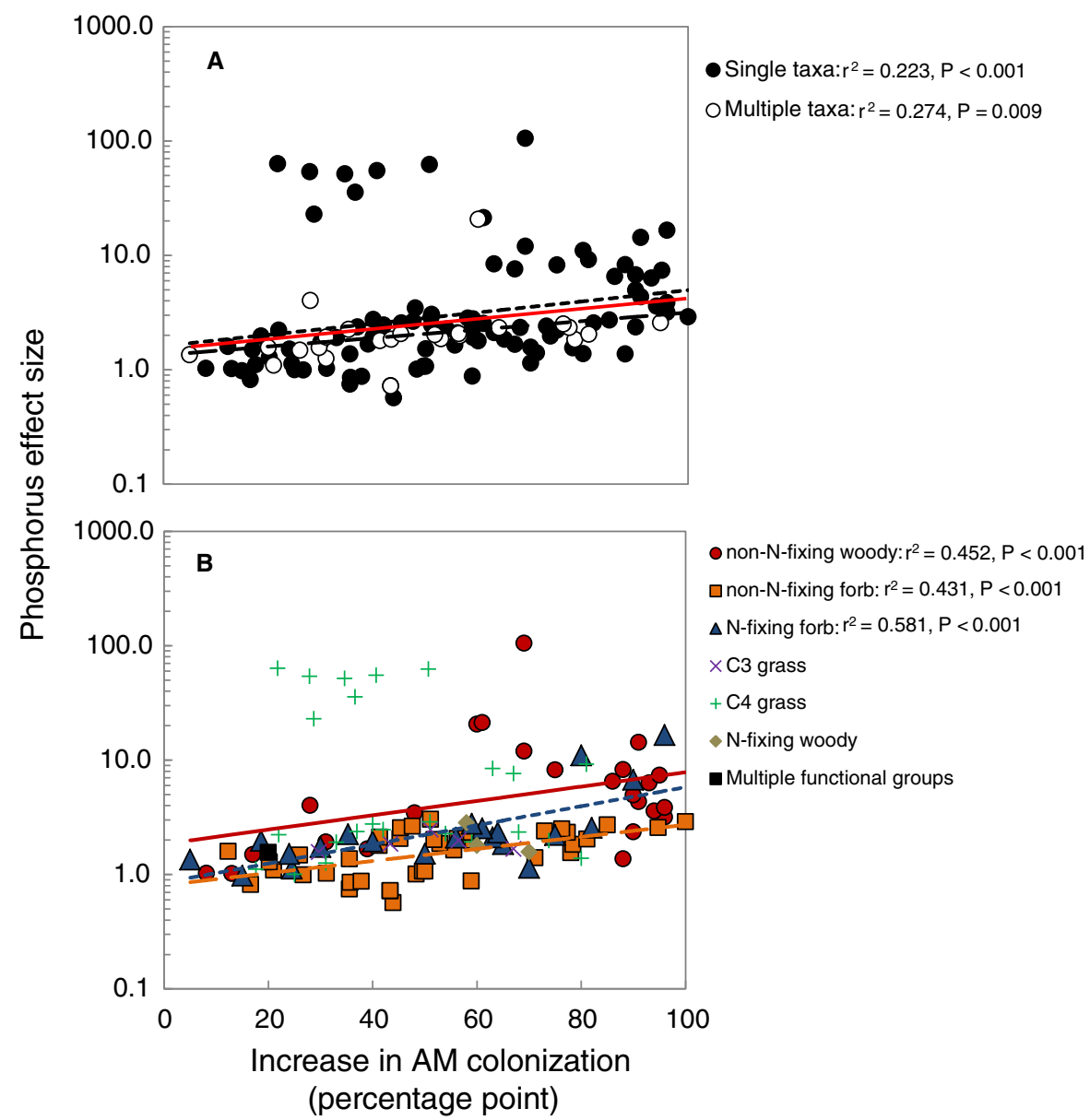


the more common assessment (and the one used by Hoeksema and colleagues).

Hoeksema et al. (2010) reported that plant functional groups differed in their responses to the presence versus absence of mycorrhizal fungi, with non-N-fixing forbs and woody plants and $\mathrm{C} 4$ grasses displaying the greatest biomass effect. Plant functional groups were similarly influential in the current study. Here, non-N-fixing woody plants and $\mathrm{C} 4$ grasses displayed greater sensitivity of plant P content to $\triangle$ PRLC (Figs. 3 and 4). For instance, in the $\mathrm{C} 4$ grass Panicum virgatum, a relatively minor $\triangle \mathrm{PRLC}$ of 20-30 percentage points resulted in a 20 - to 60-fold increase in plant $\mathrm{P}$ content (Clark et al. 1999). This pattern could have resulted from better nutrient use efficiency of these plant functional groups compared to the others. Non-N-fixing woody plants and C4 plants can display fairly efficient retention of $\mathrm{P}$ within tissues (Chapin 1980; Ehleringer and Monson 1993; Aerts 1996), which could elicit higher total $P$ content within the plant. Thus, small increases in nutrient uptake via AMF could translate to relatively large increases in $\mathrm{P}$ content. Soil $\mathrm{P}$ supply may also have interacted with plant functional group in influencing $\mathrm{P}$ effects in specific studies.

Even though relationships between $\triangle \mathrm{PRLC}$ and plant biomass and $\mathrm{P}$ effects were highly significant, $\triangle$ PRLC did not explain the majority of variation in either effect. In analyses that included all studies, $\triangle$ PRLC explained only $11.8 \%$ of the variation in plant biomass effect (Fig. 1), and $23.5 \%$ in plant $\mathrm{P}$ effect (Fig. 4). These relatively low $r^{2}$ values are not uncommon in meta-analyses, which compile data from studies that typically differ in multiple factors. For example, methods of measuring PRLC can vary in terms of type of stain, number of intersects, and identification of AMF (versus non-AMF) structures (Vierheilig et al. 2005). Moreover, the choice of host plants, study settings, AMF taxa, and differences in assessments of plant biomass and plant $\mathrm{P}$ content could each have interacted with responses to $\triangle$ PRLC. For instance, most studies were conducted in laboratory settings (Online Resource 1), which requires relatively small-statured plants. Furthermore, laboratory studies often harbor artificial conditions such as low initial AMF abundance, lack of established AMF hyphal networks, or atypical P availability. Another issue to consider is that completely effective controls are rare in AMF experiments (reviewed in Brundrett 1991), so PRLC levels are not fully independent of other factors in trials. In addition, two AMF orders were not included: Paraglomerales and Archaeosporales. Thus, generalizations to natural ecosystems, particularly those with mature forest trees, or those containing the unrepresented AMF taxa, may be problematic.

In conclusion, PRLC significantly influenced AMF effects on plant biomass and $\mathrm{P}$ concentrations across a broad selection of field- and laboratory-based based trials with a variety of AMF taxa and plant functional groups. These findings suggest that PRLC can serve as a rough metric of AMF benefits to host plants. Moreover, AMF taxa varied in the efficiency with which they augmented plant biomass, with Funneliformis as particularly beneficial to plant biomass. These relationships may allow researchers to interpret changes in PRLC in the context of general effects on plant growth and $\mathrm{P}$ status. For example, restoration or agricultural practices that yield an increase in PRLC may likewise augment AMF benefits to host plants, especially where Funneliformis is common.

Acknowledgments I am grateful to the researchers whose work is included in the meta-analysis and phylogenetic work. This manuscript was supported by a grant from the UCI Center for Environmental Biology.

\section{References}

Abbott LK, Robson AD (1985) Formation of external hyphae in soil by four species of vesicular arbuscular mycorrhizal fungi. New Phytol 99:245-255

Abbott LK, Robson AD (1991) Factors influencing the occurrence of vesicular arbuscular mycorrhizas. Agric Ecosyst Environ 35:121-150

Aerts R (1996) Nutrient resorption from senescing leaves of perennials: are there general patterns? J Ecol 84:597-608

Alkan N, Gadkar V, Coburn J, Yarden O, Kapulnik Y (2004) Quantification of the arbuscular mycorrhizal fungus Glomus intraradices in host tissue using real-time polymerase chain reaction. New Phytol 161:877-885

Alkan N, Gadkar V, Yarden O, Kapulnik Y (2006) Analysis of quantitative interactions between two species of arbuscular mycorrhizal fungi, Glomus mosseae and G. intraradices, by real-time PCR. Appl Environ Microbiol 72:4192-4199

Allen MF (1983) Formation of vesicular-arbuscular mycorrhizae in Atriplex gardneri (Chenopodiaceae): Seasonal response in a cold desert. Mycologia 75:773-776

Allen MF (2001) Modeling arbuscular mycorrhizal infection: is \% infection an appropriate variable? Mycorrhiza 10: 255-258

Allison VJ, Miller RM (2005) Using fatty acids to quantify arbuscular mycorrhizal fungi. Basic Res Appl Mycorrhizae $1: 141-162$ 
Allsopp N, Stock WD (1993) Mycorrhizal status of plants growing in the Cape Floristic Region, South-Africa. Bothalia 23:91-104

Bardgett RD (1991) The use of the membrane filter technique for comparative measurements of hyphal lengths in different grassland sites. Agric Ecosyst Environ 34:115-119

Bartelink HH (1998) A model of dry matter partitioning in trees. Tree Physiol 18:91-101

Bever JD (1994) Feedback between plants and their soil communities in an old field community. Ecology 75:1965-1977

Bever JD, Westover KM, Antonovics J (1997) Incorporating the soil community into plant population dynamics: the utility of the feedback approach. J Ecol 85:561-573

Brundett M, Bougher M, Dell B, Grove T, Malajczuk N (1996) Working with mycorrhizas in forestry and agriculture. ACIAR, Canberra, p 32

Brundrett M (1991) Mycorrhizas in natural ecosystems. Adv Ecol Res 21:171-313

Brundrett M (2004) Diversity and classification of mycorrhizal associations. Biol Rev 79:473-495

Brundrett MC (2009) Mycorrhizal associations and other means of nutrition of vascular plants: understanding the global diversity of host plants by resolving conflicting information and developing reliable means of diagnosis. Plant Soil 320:37-77

Bunn R, Lekberg Y, Zabinski C (2009) Arbuscular mycorrhizal fungi ameliorate temperature stress in thermophilic plants. Ecology 90:1378-1388

Buwalda JG, Ross GJS, Stribley DP, Tinker PB (1982) The development of endomycorrhizal root systems. III. The mathematical representation of the spread of vesicular arbuscular mycorrhizal infection in root systems. New Phytol 91:669-682

Castelli JP, Casper BB (2003) Intraspecific AM fungal variation contributes to plant-fungal feedback in a serpentine grassland. Ecology 84:323-336

Chapin FSI (1980) The mineral nutrition of wild plants. Annu Rev Ecol Syst 11:233-260

Clark RB, Zeto SK, Zobel RW (1999) Arbuscular mycorrhizal fungal isolate effectiveness on growth and root colonization of Panicum virgatum in acidic soil. Soil Biol Biochem 31:1757-1763

Da Silva GA, Lumini E, Costa Maia L, Bonfante P, Bianciotto V (2006) Phylogenetic analysis of Glomeromycota by partial LSU rDNA sequences. Mycorrhiza 16:183-189

Ehleringer JR, Monson RK (1993) Evolutionary and ecological aspects of photosynthetic pathway variation. Annu Rev Ecol Syst 24:411-439

Einsmann JC, Jones RH, Pu M, Mitchell RJ (1999) Nutrient foraging traits in 10 co-occurring plant species of contrasting life forms. J Ecol 87:609-619

Ezawa T, Smith SE, Smith FA (2002) P metabolism and transport in AM fungi. Plant Soil 244:221-230

Feldmann F, Gillessen M, Hutter I, Schneider C (2009) Should we breed for effective mycorrhiza symbioses? In: Feldmann F, Alford DV, Furk C (eds) Crop plant resistance to biotic and abiotic factors. Deutsche Phytomedizinische Gesellschaft, Braunschweig, pp 507-522

Filion M, St-Arnaud M, Jabaji-Hare SH (2003) Direct quantification of fungal DNA from soil substrate using real-time PCR. J Microbiol Methods 53:67-76
Fitter AH (1991) Costs and benefits of mycorrhizas- Implications for functioning under natural conditions. Experientia 47:350-355

Fitter AH, Merryweather JW (1992) Why are some plants more mycorrhizal than others? An ecological inquiry. In: Read DJ, Lewis DH, Alexander I (eds) Mycorrhizas in Ecosystems. CAB International. Wallingford, UK, pp 26-36

Friese CF, Allen MF (1991) The spread of VA mycorrhizal fungal hyphae in the soil: Inoculum types and external hyphal architecture. Mycologia 83:409-418

Gamper HA, Young JPW, Jones DL, Hodge A (2008) Real-time PCR and microscopy: Are the two methods measuring the same unit of arbuscular mycorrhizal fungal abundance? Fungal Genet Biol 45:581-596

Graham JH, Abbott LK (2000) Wheat responses to aggressive and non-aggressive arbuscular mycorrhizal fungi. Plant Soil 220:207-218

Guissou T, Ba AM, Ouadba JM, Guinko S, Duponnois R (1998) Responses of Parkia biglobosa (Jacq.) Benth, Tamarindus indica L. and Zizyphus mauritiana Lam. to arbuscular mycorrhizal fungi in a phosphorus-deficient sandy soil. Biol Fertil Soils 26:194-198

Hart MM, Reader RJ (2002a) Does percent root length colonization and soil hyphal length reflect the extent of colonization for all AMF? Mycorrhiza 12:297-301

Hart MM, Reader RJ (2002b) Taxonomic basis for variation in the colonization strategy of arbuscular mycorrhizal fungi. New Phytol 153:335-344

Hart MM, Reader RJ, Klironomos JN (2003) Plant coexistence mediated by arbuscular mycorrhizal fungi. Trends Ecol Evol 18:418-423

Helgason T, Merryweather JW, Denison J, Wilson P, Young JPW, Fitter AH (2002) Selectivity and functional diversity in arbuscular mycorrhizas of co-occurring fungi and plants from a temperate deciduous woodland. J Ecol 90:371-384

Hendrick RL, Pregitzer KS (1996) Temporal and depth-related patterns of fine root dynamics in northern hardwood forests. J Ecol 84:167-176

Hoeksema JD, Chaudhary VB, Gehring CA, Johnson NC, Karst J, Koide RT, Pringle A, Zabinski C, Bever JD, Moore JC, Wilson GWT, Klironomos JN, Umbanhowar $\mathrm{J}$ (2010) A meta-analysis of context-dependency in plant response to inoculation with mycorrhizal fungi. Ecol Lett 13:394-407

Isayenkov S, Fester T, Hause B (2004) Rapid determination of fungal colonization and arbuscule formation in roots of Medicago truncatula using real-time (RT) PCR. J Plant Physiol 161:1379-1383

Jackson RB, Mooney HA, Schulze ED (1997) A global budget for fine root biomass, surface area, and nutrient contents. Proc Natl Acad Sci U S A 94:7362-7366

Johnson NC, Graham JH, Smith FA (1997) Functioning of mycorrhizal associations along the mutualism-parasitism continuum. New Phytol 135:575-586

Jones MD, Smith SE (2004) Exploring functional definitions of mycorrhizas: Are mycorrhizas always mutualisms? Can J Bot-Rev Cane Bot 82:1089-1109

Karst J, Marczak L, Jones MD, Turkington R (2008) The mutualism-parasitism continuum in ectomycorrhizas: A quantitative assessment using meta-analysis. Ecology $89: 1032-1042$ 
Katoh K, Asimenos G, Toh H (2009) Multiple alignment of DNA sequences with MAFFT. In: Posada D (ed) Bioinformatics for DNA Sequence Analysis. Humana Press, New York, pp 39-64

Kattge J, Diaz S, Lavorel S, Prentice C, Leadley P, Bonisch G, Garnier E, Westoby M, Reich PB, Wright IJ, Cornelissen JHC, Violle C, Harrison SP, van Bodegom PM, Reichstein M, Enquist BJ, Soudzilovskaia NA, Ackerly DD, Anand M, Atkin O, Bahn M, Baker TR, Baldocchi D, Bekker R, Blanco CC, Blonder B, Bond WJ, Bradstock R, Bunker DE, Casanoves F, Cavender-Bares J, Chambers JQ, Chapin FS, Chave J, Coomes D, Cornwell WK, Craine JM, Dobrin BH, Duarte L, Durka W, Elser J, Esser G, Estiarte M, Fagan WF, Fang J, Fernandez-Mendez F, Fidelis A, Finegan B, Flores O, Ford H, Frank D, Freschet GT, Fyllas NM, Gallagher RV, Green WA, Gutierrez AG, Hickler T, Higgins SI, Hodgson JG, Jalili A, Jansen S, Joly CA, Kerkhoff AJ, Kirkup D, Kitajima K, Kleyer M, Klotz S, Knops JMH, Kramer K, Kuhn I, Kurokawa H, Laughlin D, Lee TD, Leishman M, Lens F, Lenz T, Lewis SL, Lloyd J, Llusia J, Louault F, Ma S, Mahecha MD, Manning P, Massad T, Medlyn BE, Messier J, Moles AT, Muller SC, Nadrowski K, Naeem S, Niinemets U, Nollert S, Nuske A, Ogaya R, Oleksyn J, Onipchenko VG, Onoda Y, Ordonez J, Overbeck G, Ozinga WA, Patino S, Paula S, Pausas JG, Penuelas J, Phillips OL, Pillar V, Poorter H, Poorter L, Poschlod P, Prinzing A, Proulx R, Rammig A, Reinsch S, Reu B, Sack L, Salgado-Negre B, Sardans J, Shiodera S, Shipley B, Siefert A, Sosinski E, Soussana JF, Swaine E, Swenson N, Thompson K, Thornton P, Waldram M, Weiher E, White M, White S, Wright SJ, Yguel B, Zaehle S, Zanne AE, Wirth C (2011) TRY - a global database of plant traits. Glob Chang Biol 17:2905-2935

Kembel SW, Cahill JF (2005) Plant phenotypic plasticity belowground: A phylogenetic perspective on root foraging trade-offs. Am Nat 166:216-230

Kivlin SN, Hawkes CV, Treseder KK (2011) Global diversity and distribution of arbuscular mycorrhizal fungi. Soil Biol Biochem 43:2294-2303

Klironomos JN (2002) Feedback with soil biota contributes to plant rarity and invasiveness in communities. Nature 417:67-70

Klironomos JN (2003) Variation in plant response to native and exotic arbuscular mycorrhizal fungi. Ecology 84:22922301

Koide RT (1991) Tansley Review No. 29: Nutrient supply, nutrient demand and plant response to mycorrhizal infection. New Phytol 117:365-386

Koske RE, Gemma JN (1989) A modified procedure for staining roots to detect VA mycorrhizas. Mycol Res 92:486-505

Krüger M, Krüger C, Walker C, Stockinger H, Schüßler A (2012) Phylogenetic reference data for systematics and phylotaxonomy of arbuscular mycorrhizal fungi from phylum to species level. New Phytol 193:970-984

Lekberg Y, Koide RT (2005) Is plant performance limited by abundance of arbuscular mycorrhizal fungi? A metaanalysis of studies published between 1988 and 2003 . New Phytol 168:189-204

Lendenmann M, Thonar C, Barnard RL, Salmon Y, Werner RA, Frossard E, Jansa J (2011) Symbiont identity matters: carbon and phosphorus fluxes between Medicago truncatula and different arbuscular mycorrhizal fungi. Mycorrhiza 21:689-702

Liedoff AC (1999) Mantel nonparametric test calculator 2.0. School of Natural Resource Sciences, Queensland University of Technology, Australia

Liu K, Raghavan S, Nelesen S, Linder CR, Warnow T (2009) Rapid and accurate large-scale coestimation of sequence alignments and phylogenetic trees. Science 324 : $1561-1564$

Liu K, Warnow TJ, Holder MT, Nelesen SM, Yu J, Stamatakis AP, Linder CR (2012) SATe-II: Very fast and accurate simultaneous estimation of multiple sequence alignments and phylogenetic trees. Syst Biol 61:90-106

Maherali H, Klironomos JN (2007) Influence of phylogeny on fungal community assembly and ecosystem functioning. Science 316:1746-1748

McGee PA (1990) Survival and growth of seedlings of coachwood (Ceratopetalum apetalum): Effects of shade, mycorrhizas and a companion plant. Aust J Bot 38: 583-592

McGonigle TP, Miller MH, Evans DG, Fairchild GL, Swan JA (1990) A new method which gives an objective measure of colonization of roots by vesicular-arbuscular mycorrhizal fungi. New Phytol 115:495-501

Mosse B (1957) Growth and chemical composition of mycorrhizal and non-mycorrhizal apples. Nature 179:922-924

Mosse B (1973) Advances in the study of vesicular-arbuscular mycorrhiza. Annu Rev Phytopathol 11:171-196

Munkvold L, Kjoller R, Vestberg M, Rosendahl S, Jakobsen I (2004) High functional diversity within species of arbuscular mycorrhizal fungi. New Phytol 164:357-364

Nadian H, Smith SE, Alston AM, Murray RS (1997) Effects of soil compaction on plant growth, phosphorus uptake and morphological characteristics of vesicular-arbuscular mycorrhizal colonization of Trifolium subterraneum. New Phytol 135:303-311

Nye PH, Tinker PB (1977) Solute movement in the soil-root system. University of California Press, Berkeley

Olsson PA, Baath E, Jakobsen I, Soderstrom B (1995) The use of phospholipid and neutral lipid fatty acids to estimate biomass of arbuscular mycorrhizal fungi in soil. Mycol Res 99:623-629

Ostertag R (2001) Effects of nitrogen and phosphorus availability on fine-root dynamics in Hawaiian montane forests. Ecology 82:485-499

Ozgonen H, Erkilic A (2007) Growth enhancement and Phytophthora blight (Phytophthora capsici Leonian) control by arbuscular mycorrhizal fungal inoculation in pepper. Crop Prot 26:1682-1688

Powell JR, Parrent JL, Hart MM, Klironomos JN, Rillig MC, Maherali H (2009) Phylogenetic trait conservatism and the evolution of functional trade-offs in arbuscular mycorrhizal fungi. Proc R Soc B Biol Sci 276:4237-4245

Price MN, Dehal PS, Arkin AP (2010) FastTree 2- approximately maximum-likelihood trees for large alignments. PLoS One 5:e9490

Pritchard SG, Strand AE, McCormack ML, Davis MA, Finzi AC, Jackson RB, Matamala R, Rogers HH, Oren R (2008) Fine root dynamics in a loblolly pine forest are influenced by free-air- $\mathrm{CO}_{2}$-enrichment: a six-year-minirhizotron study. Glob Chang Biol 14:588-602 
Read DJ (1984) The structure and function of the vegetative mycelium of mycorrhizal roots. In: Jennings DH, Rayner ADM (eds) The ecology and physiology of the fungal mycelium. Cambridge University Press, Cambridge, pp 215-240

Redecker D (2002) Molecular identification and phylogeny of arbuscular mycorrhizal fungi. Plant Soil 244:67-73

Redecker D, Raab P (2006) Phylogeny of the Glomeromycota (arbuscular mycorrhizal fungi): recent developments and new gene markers. Mycologia 98:885-895

Reynolds HL, Dantonio C (1996) The ecological significance of plasticity in root weight ratio in response to nitrogen: Opinion. Plant Soil 185:75-97

Rhodes LH, Gerdemann JW (1975) Phosphate uptake zones of mycorrhizal and non-mycorrhizal onions. New Phytol 75:555-561

Sanders FE, Tinker PB (1973) Phosphate flow into mycorrhizal roots. Pestic Sci 4:385-395

Sanders FE, Tinker PB, Black RLB, Palmerley SM (1977) The development of endomycorrhizal root systems. I. Spread of infection and growth promoting effects with four species of vesicular-arbuscular mycorrhizas. New Phytol 78:257-268

Schenk HJ, Jackson RB (2002a) The global biogeography of roots. Ecol Monogr 72:311-328

Schenk HJ, Jackson RB (2002b) Rooting depths, lateral root spreads and below-ground/above- ground allometries of plants in water-limited ecosystems. J Ecol 90:480-494

Schüßler A, Walker C (2010) The Glomeromycota: a species list with new families and genera. The Royal Botanic Garden, Botanische Staatssammlung Munich, and Oregon State University, Edinburgh

Schweiger P, Jakobsen I (2000) Laboratory and field methods for measurement of hyphal uptake of nutrients in soil. Plant Soil 226:237-244

Sensoy S, Demir S, Turkmen O, Erdinc C, Savur OB (2007) Responses of some different pepper (Capsicum annuum L.) genotypes to inoculation with two different arbuscular mycorrhizal fungi. Sci Hortic 113:92-95

Siqueira JO, Carneiro MAC, Curi N, Rosado SCS, Davide AC (1998) Mycorrhizal colonization and mycotrophic growth of native woody species as related to successional groups in Southeastern Brazil. For Ecol Manag 107:241-252

Smith SE, Gianinazzi-Pearson V (1990) Phosphate uptake and arbuscular activity in mycorrhizal Allium cepa L: Effects of photon irradiance and phosphate nutrition. Aust J Plant Physiol 17:177-188

Smith SE, Read DJ (2008) Mycorrhizal Symbiosis, 3rd edn. Academic, San Diego

Smith FA, Smith SE (1996) Mutualism and parasitism: Diversity in function and structure in the "arbuscular" (VA) mycorrhizal symbiosis. Adv Bot Res 22:1-43

Smith FA, Smith SE (2011a) What is the significance of the arbuscular mycorrhizal colonisation of many economically important crop plants? Plant Soil 348:63-79

Smith SE, Smith FA (2011b) Roles of arbuscular mycorrhizas in plant nutrition and growth: New paradigms from cellular to ecosystem scales. In: Merchant SS, Briggs WR, Ort D (eds) Ann Rev Plant Biol 62:227-250

Smith SE, Smith FA (2012) Fresh perspectives on the roles of arbuscular mycorrhizal fungi in plant nutrition and growth. Mycologia 104:1-13

Smith SE, Smith FA, Jakobsen I (2004) Functional diversity in arbuscular mycorrhizal (AM) symbioses: the contribution of the mycorrhizal P uptake pathway is not correlated with mycorrhizal responses in growth or total $\mathrm{P}$ uptake. New Phytol 162:511-524

Stuermer SL (2012) A history of the taxonomy and systematics of arbuscular mycorrhizal fungi belonging to the phylum Glomeromycota. Mycorrhiza 22:247-258

Stulen I, Denhertog J (1993) Root growth and functioning under atmospheric $\mathrm{CO}_{2}$ enrichment. Vegetatio 104:99-115

Sylvia DM (1992) Quantification of external hyphae of vesiculararbuscular mycorrhizal fungi. In: Norris JR, Read D, Varma AK (eds) Techniques for mycorrhizal research. Academic, London, pp 513-525

Tisserant B, Gianinazzi-Pearson V, Gianinazzi S, Gollotte A (1993) In planta histochemical staining of fungal alkaline phosphatase activity for analysis of efficient arbuscular mycorrhizal infections. Mycol Res 97:245-250

Tisserant B, Gianinazzi S, GianinazziPearson V (1996) Relationships between lateral root order, arbuscular mycorrhiza development, and the physiological state of the symbiotic fungus in Platanus acerifolia. Can J Bot-Rev Can Bot 74:1947-1955

Treseder KK (2005) Nutrient acquisition strategies of fungi and their relation to elevated atmospheric $\mathrm{CO}_{2}$. In: Dighton J, Oudemans P, White J (eds) The fungal community. Marcel Dekker, pp 713-731

Troughton A (1956) Studies on the growth of young grass plants with special reference to the relationship between the shoot and root systems. J Br Grassland Soc 11:56-65

van der Heijden MGA, Boller T, Wiemken A, Sanders IR (1998) Different arbuscular mycorrhizal fungal species are potential determinants of plant community structure. Ecology 79:2082-2091

Vierheilig H, Schweiger P, Brundrett M (2005) An overview of methods for the detection and observation of arbuscular mycorrhizal fungi in roots. Physiol Plant 125:393-404

Vosátka M, Dodd JC (1998) The role of different arbuscular mycorrhizal fungi in the growth of Calamagrostis villosa and Deschampsia flexuosa, in experiments with simulated acid rain. Plant Soil 200:251-263

Walker NA, Smith SE (1984) The quantitative study of mycorrhizal infection. II. The relation of rate of infection and speed of fungal growth to propagule density, the mean length of the infection unit and the limiting value of the fraction of the root infected. New Phytol 96:55-69

Watanarojanaporn N, Boonkerd N, Wongkaew S, Prommanop P, Teaumroong N (2011) Selection of arbuscular mycorrhizal fungi for citrus growth promotion and Phytophthora suppression. Sci Hortic 128:423-433

Young JPW (2012) A molecular guide to the taxonomy of arbuscular mycorrhizal fungi. New Phytol 193:823-826 